\title{
The Effect of Prophetic Leadership on Employee Engagement At sufism-based Islamic Boarding School
}

\author{
Irfan Budiono ${ }^{1}$, Hamidah $^{2}$ and Mahmuddin Yasin ${ }^{2,3}$ \\ \{irfanbudiono_im16s3@mahasiswa.unj.ac.id ${ }^{1}$ \} \\ Human Resource Management, State University of Jakarta, Indonesia ${ }^{1}$, Jakarta State University ${ }^{2}$, \\ Krisnadwipayana University ${ }^{3}$
}

\begin{abstract}
The purpose of this study is to analyze the effect of prophetic leadership on employee engagement among educators in an Islamic boarding school. This research is a quantitative research data collection through surveys in the boarding school of Sufism based in Tasikmalaya, Indonesia, using a questionnaire to collect data. The study sample consisted of 161 educators boarding school. The data was analyzed using SEM with the AMOS 24 program, to test the effects Research findings showed a significant prophetic leadership influence employee engagement. Originality of this research lies both on the unit analysis of educators at sufism-base Islamic boarding school and the models that reflects the effects of prophetic leadership on employee engagement.
\end{abstract}

Keywords: prophetic leadership, employee engagement, and sufism-base Islamic boarding school

\section{Introduction}

Pesantren Idrisiyyah is a sufism-based Islamic boarding school with 2406 students (santri) and 241 educators established in 1932. Pesantren Idrisiyyah applies tariqa management and educational model of theoretical teaching and community direct involvement with a top down pattern of dynamic authority dependence greatly on the murshid (tareqa leadership).

Pesantren leaders of the central figures who are in boarding school and its leadership has its own characteristics in comparison with existing leadership in other educational institutions. Especially pesantren leaders are patterned Sufism or the use of management institutes. Referring to the definition of tariqa and its establishment, tariqa is an organisation, that [1]. mentioned it as a sufi order, that is indicated by an extreme obedience and is internalized among its followers with fanaticism to the sufi master. At first, tariqa is a method in order to get closer to Allah and is group of people under leadership of a Shaykh. At later stage, these groups of people turned into binding institutions with set of orders defined by a Shaykh [2].

The figure of a leader must be able to serve his people, and the servant leadership is in the Prophet Muhamma [3], There is a strong relationship between the level of servant leadership with employee engagement [4], There is a strong correlation between the servicing leadership employee engagement in higher education institutions [5], Strong support for the servant leadership that predict work-life balance and three-dimensional work engagement 
Behaviour from supervisors has a significant on engagement at work [6]. The central role and dominance of pesantren leaders, can result in lower aspects, the enthusiasm, initiative, freedom of work, which is a dimension of employee engagement.

Based on the existing problems, the goal of this research is to analyze the effect of prophetic leadership on employee engagement among educators in an Islamic boarding school. Given that no one has conducted a study that links prophetic leadershp among educators in Islamic boarding schools with employee engagement, especially in Sufism-based Islamic boarding schools where a leader or murshid is very dominance, this research becomes interesting and has an element of scarcity and novelty (state of the art).

\section{Literature Review}

\subsection{Prophetic leadership}

Theoretically prophetic leadership is leadership based on life experience of the prophet. Leadership that leads all of its aspects and elements in the life and leadership of all circumstances, the process of decision-making and managerial expertise of the Prophet, the Prophet's build leadership models and build leaders - followers in mutually beneficial cooperation [7]. Prophetic Leadership is influence and direct action working soul, qolbu, mind, thought, sensory, and behavioral bodies together and integrated [8], Prophetic Leadership is the ability to control themselves and influence others with sincere to achieve common goals such as what has been done prophets, through four aspects, namely sidiq Amanah, Tabligh, and fathonah.[9]. Prophetic leadership also show leadership and social network theory, the need to find common ground and synergies between leaders and followers and altruistic management to build leadership effectiveness. [10]

\subsection{Employee Engagement}

Employee engagement also defined as a positive outlook and attitude of employees towards the organization, along with the value system that is in it. [11] There are three elements in employee engagement, namely (1) a positive outlook on life and work, (2) a sense of energy, and (3) conduct that exceeds the required tasks.[12], Employee engagement is a personal engagement and satisfaction as a form of enthusiasm to work. Employees who are engaged show loyal behavior, motivation and work to show better performance [13], There are four components of engagement, namely: 1) vigor. a passion or desire to try to really ungguh work, persistent in the struggle with the problem. 2) dedication, a feeling, enthusiasm, inspirastif, pride, a sense of meaningful and challenging job. 3) absorbtion, a feeling bonded to the job, because it is very interested in the job, so that dissolved with the job, and it's hard to separate himself with work [14], Employee engagement is sensitiftas sense and intelligence are no employees associated with the job, the organization, managers, co-workers, who can give effect to increase the freedom to choose the way in his work [15]. Employee engagement is a unique construction that consists of components of cognitive, emotional, and behavior related to the performance of individual roles[16], Employee engagement is when employees connected with, satisfied, and enthusiastic about their jobs [17],

\subsection{The Effect of the prophetic leadership on the employee engagement}

Strong factors that may affect employee engagement an employee is leadership, [11] When leaders have clear expectations or equitable, and recognize good performance, leaders will have a positive effect on employee engagement by giving birth to a sense of attachment to the job [12], Leadership can increase the sense of engagement, teamwork, commitment, 
competence, and employee performance [18], There is a relationship between leadership and employee engagement. Confidence in the leader, leader support, and the creation of an environment free from psychological security components that enable employee engagement [19], Leadership has a positive relationship with employee engagement. [20], There is a positive relationship between supervisor and employee engagement support [21], There is a high correlation between the senior leadership and several other driving employee engagement in organizations [22], Transformational leadership style has a positive relationship with employee engagement. Similarly, transactional leadership style also has a positive relationship with employee engagement [23], Opinions noted previously led to the conclusion that: There is a direct positive influence between the prophetic leadership to employee engagement.

\section{Method}

The study uses a survey method using analysis techniques Structural Equation Model (SEM), by AMOS 24 program and the maximum likelihood estimation approach.. The sample in this study is 161 educators in a boarding school (pesantren) Idrisiyyah. The sampling technique is probability sampling using simple random sampling, a random sampling regardless of the strata in the population.

All constructs in the study was measured using Likert scale (Likert scale), with a range of values from 1 to 5 with choice answers of Never" (TP) $=1$ up to "Always" (SL) $=5$ in order to measure the construct the prophetic leadership. The range is between "Strongly Disagree" $(\mathrm{ST})=1$ up to "Strongly Agree" ( SS) $=5$ in order to measure the construct the employee engagement..

\section{$4 \quad$ Result And Discusion}

\subsection{Result}

\begin{tabular}{l|cccccc}
\hline Model & GFI & AGFI & TLI & CFI & RMSEA & CMIN / DF \\
\hline default models &, 858 &, 807 &, 937 &, 948 &, 080 & 2,016 \\
\hline
\end{tabular}

The test results (see table 1) show that the model full model can be categorized meet the criteria of fit, it's based criteria have been fulfilled several criteria of goodness of fit. The results of chi-square test calculations in obtaining a full model chi-square value of 254.00 is still above the chi-square table for 126 degrees of freedom at a significant level of $1 \%$ at 165.841. A probability value of 0.000 which is below the value of 0.01 . Value CMIN / DF amounted to 2,016 (marginal) slightly above 2.00. GFI value of 0.858 (Marginal), slightly below the 0.90 ;. AGFI value of 0.807 (Marginal), slightly under 0.90; TLI value of 0.937 (good) above 0.90. CFI value of 0.948 (good) which value is above 0.90 and below RMSEA value of 0.080 (good) which is equal to the value of 0.08 . 
Table 2. Standardized Regression Weights

\begin{tabular}{|c|c|c|c|c|c|c|c|}
\hline \multicolumn{7}{|c|}{ estimate } & \multirow[t]{2}{*}{ estimate } \\
\hline $\mathrm{EE}$ & $<--$ & PL &, 663 & & & & \\
\hline $\mathrm{X} 1$ & $<---$ & PL &, 780 & X9 & $<---$ & PL &, 857 \\
\hline $\mathrm{X} 2$ & $<---$ & PL &, 763 & $\mathrm{X} 10$ & $<--$ & PL &, 817 \\
\hline $\mathrm{X} 3$ & $<---$ & PL & , 907 & $\mathrm{X} 11$ & $<---$ & PL &, 815 \\
\hline X4 & $<---$ & PL & 726 & $\mathrm{X} 12$ & $<---$ & $\mathrm{EE}$ &, 707 \\
\hline X5 & $<---$ & PL &, 820 & $\mathrm{X} 13$ & $<---$ & $\mathrm{EE}$ &, 721 \\
\hline X6 & $<---$ & PL & , 839 & X14 & $<---$ & $\mathrm{EE}$ &, 847 \\
\hline $\mathrm{X} 7$ & $<---$ & PL &, 865 & $\mathrm{X} 15$ & $<---$ & $\mathrm{EE}$ &, 851 \\
\hline $\mathrm{X} 8$ & $<---$ & PL &, 725 & X16 & $<---$ & $\mathrm{EE}$ &, 839 \\
\hline
\end{tabular}

Value factor loading all indicators (see table 2) show the estimated value of which is in the range of 0.707 and 0.907 value. This means that this value is above the limit value of 0.5 is used as the criteria, so the model is considered fit and able to continue to the next test. Based on the results of variance extract and the reliability contruct obtained variance extract value 0.660 , for the leadership prophetic and 0.616 for employee engagement As for reliability contruct, the value of 0.955 for prophetic leadership, and 0.918 for employee engagement. Value of Variance extract and the reliability contruct obtained showed a good value, which implies there are indicators that can explain the construct.

Table 3. Variance extract and reliability contruct

\begin{tabular}{lrr}
\hline \multicolumn{1}{c}{ variable } & reliability contruct & variance extract \\
\hline Prophetic Leadership & 0.955 & .660 \\
Employee Engagement & 0.918 & .616 \\
\hline
\end{tabular}

Testing Statistical Hypotheses on the hypothesis of a positive relationship between the prophetic leadership on employee engagement, can be seen with CR values obtained from the regression weight Maximum Likelihood Estimates (see table 4). CR value with a probability of 6.773 and $* * *$. qualify for acceptance of the hypothesis, which value CR greater than 1.96, and the probability is less than 0.05 . So there is positive and significant correlation between the prophetic leadership to employee engagement.

Table 4. Summary Regression Weights

\begin{tabular}{|c|c|c|c|c|c|c|}
\hline & & estimate & $\mathrm{SE}$ & $\mathrm{CR}$ & $\mathrm{P}$ & Label \\
\hline $\begin{array}{c}\text { Employee } \\
\text { Engagement }\end{array}$ & $\begin{array}{l}\text { Prophetic } \\
\text { Leadership }\end{array}$ &, 506 &, 075 & 6.773 & $* * *$ & par_17 \\
\hline
\end{tabular}

\subsection{Discussion}

The finding shows that the prophetic leadership provides a directly positive influence on the employee engagement. This is consistent with the arguments raised by [11] ; [24] that say 
a leadership will have a positive impact on the employee engagement by feeling an engagement on jobs. It is also consistent with the research made by [18]; [19]; [20]; [21]; [23].

Tariqa Idrisiyyah is one of the tariqa that shows a different leadership style and organizational character compared to most of other tariqa. The results of different studies with the view of the public and researchers in general. Although it is tariqa-based, Pesantren Idrisiyyah does not avoid science. Pesantren Idrisiyyah runs its organization based on an accountable and transparent management [25]. In Pesantren Idrisiyyah, sufism becomes the basis for entrepreneurship among murid (followers). Pesantren Idrisiyyah applies a model that combine theoretical approach and a direct participation in society through various business units in order to impose economic self-sufficiency [26]. That makes Idrisiyyah recognized as a pioneer of neo-sufism in Indonesia [27] Prophetic leadership of the murshid in the tariqa idrisiyyah duties and function of spirituality and intellect educate his students. Under the conditions of organizational development and advancement of the tariqa Idrisiyyah and pesantren, it can be understood that prophetic leadership in the tariqa Idrisiyyah positive effect on employee engagement.

\section{Conclusion}

Conclusions of this research is The prophetic leadership provides a significantly positive influence on the employee engagement among educators in pesantren Idrisiyyah

\section{References}

[1] J. S. Trimingham, The Sufi Order in Islami. New York: Oxford University Press, 1973.

[2] A. W. K. Humam, Satu Tuhan Seribu Jalan, Sejarah, ajaran, dan Gerakan Tarekat di Indonesia. Yogyakarta: FORUM, 2013.

[3] J. Adair, Kepemimpinan Muhammad. Jakarta: PT. Gramedia Pustaka Utama, 2010.

[4] J. J. Kell, "Examining Servant Leadership and Employee Engagement In A Financial Services Industry Organization: A Descriptive Survey Study," Capella University, 2010.

[5] J. Varney, "The Impact of Servant Leadership on the Engagement of Adjunct Higher Education Online Faculty," Concordia University-Chicago, 2016.

[6] V. Gupta, S. Singh, and A. Bhattacharya, "The Relationships Between Leadership, Work Engagement and Employee Innovative Performance: Empirical Evidence From The Indian Rd Context," Int. J. Innov. Manag., vol. 21, no. 07, p. 1750055, 2017.

[7] N. Maheran Nik Muhammad, "Prophetic Leadership Model: Conceptualizing a Prophet 's Leadership Behaviour, Leader - Follower Mutuality and Altruism to Decision Making Quality,” Eur. J. Interdiscip. Stud., vol. 3, no. 1, pp. 93-106, 2015.

[8] H. B. Adz-Dzakiey, Kepemimpinan Kenabian (Prophetic Leadership), Cet. Ke 1. Yogyakarta: Al-Manar, 2009.

[9] S. Budiharto and F. Himam, "Konstruk Teoritis dan Pengukuran Kepemimpinan Profetik," J. Psikol., vol. 33, no. 2, pp. 133-146, 2006.

[10] N. Maheran N M and S. Akbarzadeh, "Prophetic Leadership and Financial Decision Making Quality: Partial Least Square ( PLS ) Path Modeling Analysis .," Int. J. Bus. Manag. Stud., vol. 2, no. 1, pp. 195-213, 2013.

[11] D. Robinson, S. Perryman, and S. Hayday, "The Drivers of Employee Engagement," Inst. emplyoment Stud., vol. 408, pp. 12-15, 2004.

[12] W. H. Macey and B. Schneider, "The Meaning of Employee Engagement," Ind. Organ. 
Psychol., vol. 1, no. 01, pp. 3-30, 2008.

[13] J. K. Harter, F. L. Schmidt, and T. L. Hayes, "Business-unit-level relationship between employee satisfaction, employee engagement, and business outcomes: A meta-analysis," $J$. Appl. Psychol., vol. 87, no. 2, pp. 268-279, 2002.

[14] W. B. Schaufeli, I. M. Martínez, A. M. Pinto, M. Salanova, and A. B. Barker, "Burnout and engagement in university students a cross-national study," J. Cross. Cult. Psychol., vol. 33, no. 5, pp. 464-481, 2002.

[15] L. Branham and M. Hirschfeld, Re Engage. New York: McGraw-Hill, 2010.

[16] A. M. Saks, "Workplace spirituality and employee engagement," J. Manag. Spiritual. Relig., vol. 8, no. 4, pp. 317-340, 2011.

[17] M. Robbins, Stephen P, Coultier, Management, Eleventh E. New Jersey: Pearson Education, Inc., publishing as Prentice Hall, 2012.

[18] B. Shamir, R. J. House, and M. B. Arthur, "The Motivational Effects Of Charismatic Leadership: A Self-Concept Based Theory,” Organ. Sci., vol. 4, no. 4, pp. 577-594, 1993.

[19] W. A. Kahn, "Psychological Conditions of Personal Engagement and Disengagement At Work.," Acad. Manag. J., vol. 33, no. 4, pp. 692-724, 1990.

[20] J. B. Avey, L. W. Hughes, S. M. Norman, and K. W. Luthans, "Using positivity, transformational leadership and empowerment to combat employee negativity," Leadersh. Organ. Dev. J., vol. 29, no. 2, pp. 110-126, 2016.

[21] A. M. Saks, "Antecedents and consequences of employee engagement," J. Manag. Psychol., vol. 21, no. 7, pp. 600-619, 2006.

[22] A. Hewitt, "The Multiplier Effect: Insights into How Senior Leaders Drive Employee Engagement Higher," Aon Hewitt, pp. 1-8, 2011.

[23] S. Popli and I. A. Rizvi, "Drivers of employee engagement: The role of leadership style," Glob. Bus. Rev., vol. 17, no. 4, pp. 965-979, 2016.

[24] W. H. Macey and B. Schneider, "Engaged in Engagement: We Are Delighted We Did It," Ind. Organ. Psychol., vol. 1, no. 01, pp. 76-83, 2008.

[25] T. Priatna, Nurhamzah, T. Ratnasih, and H. S. Siregar, "Educational financing management in tarekat - based pesantren," J. Pendidik. Islam, vol. 4, no. 1, pp. 63-74, 2018.

[26] U. Suryatman, "PESANTREN DAN KEMANDIRIAN EKONOMI KAUM SANTRI," $J$. alTsaqafa, vol. 14, no. 02, p. 14, 2017.

[27] S. B. Pili, Tarekat Idrisiyyah, Sejarah dan ajarannya. Tasikmalaya: Mawahib, 2019. 